UCRL-CR--107484

DE92 002644

NOV i 2900

\title{
DEVELOPMENT OF MODELS FOR USE IN THE ASSESSMENT OF WASTE REPOSITORY PERFORMANCE ANNUAL PROGRESS REPORT
}

A.G. Dickson

J.H. Weare

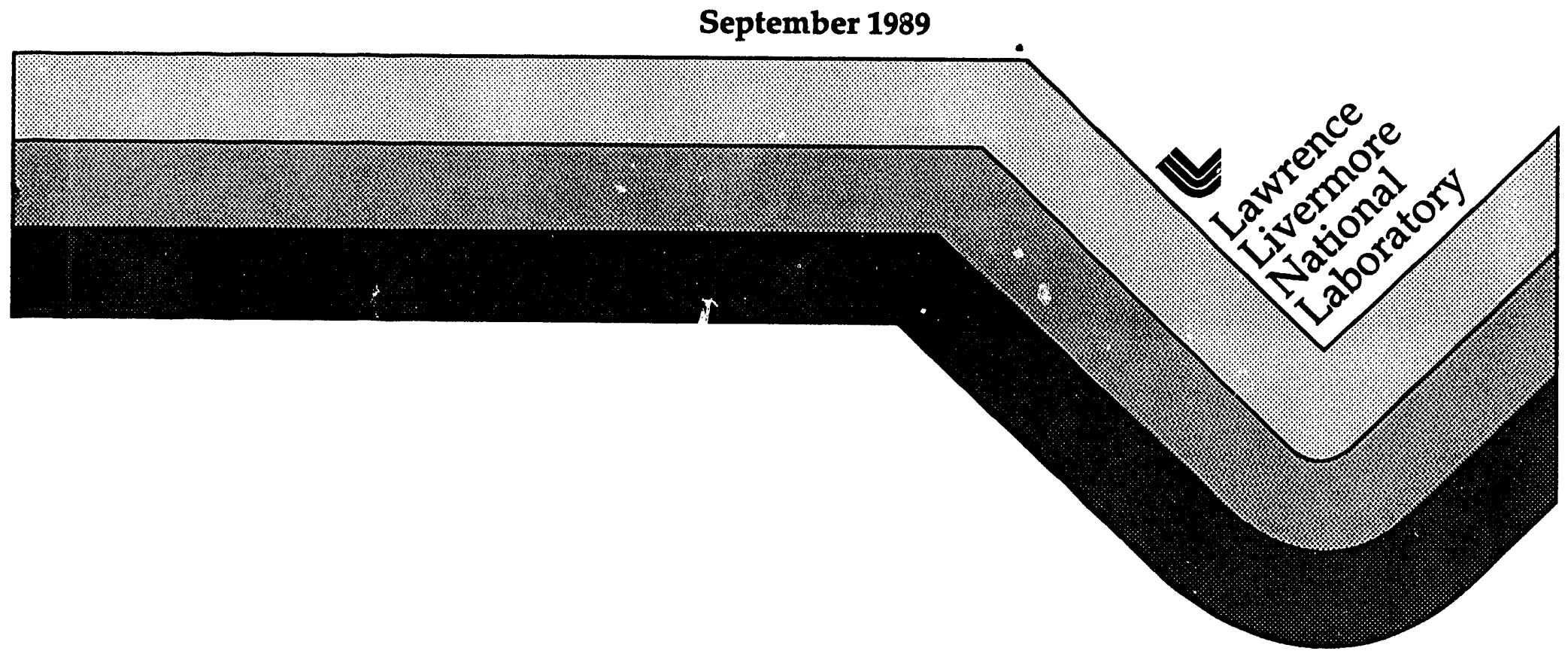




\section{DISCLAIMER}

Work performed under the auspices of the U.S. Department of Energy by Lawrence Livermore National Laboratory under contract number W-7405-ENG-48.

This document was prepared as an account of work sponsored by an agency of the United States Government. Neither the United States Government nor the University of California nor any of thei employees, makes any warranty, express or implied, or assumes any legal liability or responsibility for the accuracy, completeness, or usefulness of any information, apparatus, product, or process disclosed, or represents that its use would not infringe privately owned rights. Reference herein to any specific commercial products, process, or service by trade name, trademark, manufacturer, or otherwise, does not necessarily constitute or imply its endorsement, recommendation, or favoring by the United States Government or the University of California. The views and opinions of authors expressed herein do not necessarily state or reflect those of the United States Government or the University of California, and shall not be used for advertising or product endorsement purposes. 


\title{
THE REGENTS OF THE UNIVERSITY OF CALIFORNIA UNIVERSITY OF CALIFORNIA, SAN DIEGO
}

Scripps Institution of Oceanography, Mail Code A-010

La Jolla, California

Telephone (619)534-4570

\section{ANNUAL PROGRESS REPORT}

\author{
University of California \\ Lawrence Livermore National Laboratory \\ P.O. Box 808 \\ Livermore, CA 94551
}

Attn: Dr. Robert J. Silva, Nuclear Chemistry, L-232

Title of Proposal: Development of Models for Use in the

Assessment of Waste Repository Performance

Project Period: $\quad$ From: 1 November 1988 Through: 30 September 1989

Agency Contract or Grant No.: LLNL Purchase Order \#B076243

Principal Investigators:

A.G. Dickson, Marine Physical Laboratory, University of California, San Diego, CA 92093, (619)534-2582

J.H. Weare, Chemistry Department, University of California, San Diego, CA 92093, (619)534-3286

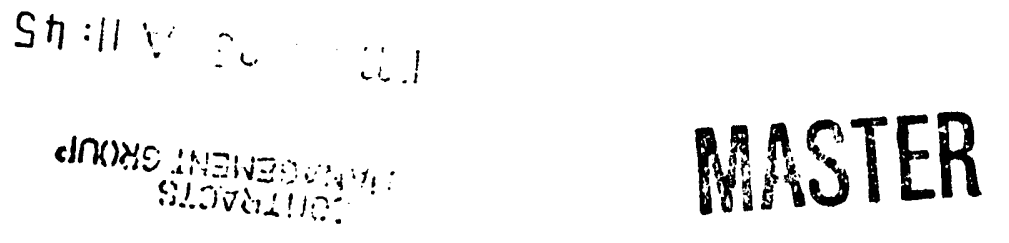

DISTRIBUTION OF THIS DOCUMENT IS UNLIMITED 


\section{ABSTRACT}

The work outlined in this proposal is intended both to provide thermodynamic data that is needed to assist in the assessment of waste repository performance and the modeling necessary to ascertain to what extent the data produced is consistent, both with itself and with other published data on related systems.

In our previous work funded through L.L.N.L. and the Yucca Mountain Project, we have obtained data on the $\mathrm{AlCl}_{3} / \mathrm{HCl} / \mathrm{H}_{2} \mathrm{O}$ system over a wide range of temperatures. This data has been reported previously, and we shall prepare a paper for publication in the Journal of Solution Chemistry. We will also extend our studies on the hydrolysis of aluminum using a coulometric titration method developed during the past funding period. This approach will allow us to study the low concentration chemistry of the aluminum system over a range of $\mathrm{pH}$ vaiues. During this stage of the research we shall endeavor to develop a model of the chemistry of aluminum in aqueous solution which is consistent with a wide variety of experimental data including data generated as part of this project together with data that has been published previously in the research literature.

We also propose a program of research designed to enable us to model the interaction of canister materials (e.g. copper and iron) with natural waters. Obviously it is important to predict the behavior of the containment vessels as a function of the ground waters which may be encountered within the repository. Such chemical interactions are controlled by the activity of the reactive species in the solution phase. As in the case of aluminum, little is known about these species in natural waters. Both experimental work and a modeling program are outlined. In the experimental program e.m.f. measurements and spectroscopic measurements will be made so as to determine the various association equilibria of iron and copper with the anions $\mathrm{OH}^{-}, \mathrm{HCO}_{3}^{-}$, and $\mathrm{CO}_{3}^{2-}$. The initial stages of the modeling program will concentrate on the identification and use of existing experimental data to produce a preliminary model. This will allow us to identify those areas where special emphasis should be placed to meet the needs of the waste disposal program objectives.

The objective of this research is to produce thermodynamic data for use in the assessment of waste repository performance that has been measured using experimental procedures performed in accord with the Level 1 quality assurance requirements detailed in the L.L.N.L. Yucca Mountain Project Quality Procedures Manual. The modeling approach we shall use to assist with our experimental planning and data assessment is a Level 3 activity. In addition to the establishment of the thermodynamic data base proposed here, we believe that the collaboration of our group with the other researchers in the L.L.N.L. Y.M.P. will help lead to improved consistency in the overall modeling effort. 
UCSD 901101

\section{PROPOSED MILESTONES}

We propose the following tasks as milestones for this research.

\section{Quality Assurance Level 1}

(1) Use the coulometric procedure we developed last fiscal year to obtain hydrolysis constants for the hydrolysis of $\mathrm{Al}^{3+}$ in sodium chioride media over a range of temperatures. (Initial report 3/31/90, Final report 9/30/90)

(2) Experiments in the iron and copper systems at $25^{\circ} \mathrm{C}$. These experiments will use potentiometric and spectrophotometric procedures to produce association constants between iron and copper with the anions $\mathrm{OH}^{-}, \mathrm{HCO}_{3}^{-}$, and $\mathrm{CO}_{3}^{2-}$ both in sodium chloride and in sodium perchlorate media. (Initial report 3/31/90, Final Report 9/30/90)

(3) Initiate experiments in the iron and copper systems at higher temperatures. (Report 9/30/90)

Quality Assurance Level 3

(1) Preparation of a manuscript for submission to the Journal of Solution Chemistry detailing our previous work on the $\mathrm{AlCl}_{3} / \mathrm{HCl} / \mathrm{H}_{2} \mathrm{O}$ system. (Manuscript to L.L.N.L. for approval 12/30/89)

(2) Continue modeling the aluminum system over a range of temperatures. (Initial report $3 / 31 / 90$, Final report 9/30/90)

(3) Conduct a literature search for data in the iron and copper systems, and undertake some preliminary modeling of these systems. Identify and design experiments needed to improve these models. (Report 3/31/90)

(4) Initiate modeling of experimental results in the iron and copper systerns. (Report 9/30/90)

(5) Investigation of coulometric procedure using the $\left(\mathrm{PbO}_{2}(\mathrm{~s})+4 \mathrm{H}^{+}+2 \mathrm{Ag}(\mathrm{s})=\right.$ $\mathrm{Pb}^{2+}+2 \mathrm{Ag}^{+}+2 \mathrm{H}_{2} \mathrm{O}$ ) cell. (Report 9/30/90) 
UCSD 901101

\section{PROPOSED RESEARCH}

\section{INTRODUCTION}

Any repository suitable for the disposal of radioactive waste comprises a combination of various man-made and natural barriers which aim to prevent transfer of radionuclides from the canister to the external environment. Because of the very long lifetimes of nuclear waste products, the overall design of a repository cannot be tested successfully by laboratory simulations. Therefore the assessment of any particular design depends on understanding and modeling the behavior of the various barriers using thermodynamic and kinetic data based on laboratory experiments.

Our group has developed the techniques needed to model the equilibrium chemistry of complex multicomponent systems over a range of ionic strengths and temperatures (HARVIE and WEARE, 1980; HARVIE et al., 1980; FELMY and WEARE, 1986; MøLLER et al., in prep.). These models, which are based on the virial expansion proposed by PITZER $(1972 ; 1987)$ show remarkable agreement with field measurements when applied to natural systems. They have been successfully applied to interpret a variety of geochemical processes: studies of ancient (Zechstein II - HARVIE et al., 1980; EUGSTER et al., 1980) and modern (Bocana de Virrilà - BRANTLEY et al., 1984) marine evaporite systems, studies of the solar evaporation of seawater (MøLLER et al., in prep.), studies of mineral formation in lakes (Great Salt Lake - SPENCER et al., 1985; Searles Lake with borate species added - FELMY and WEARE, 1986), and in fluid inclusions (collaboration with B. Lazar and H. D. Holland). For a review of some of these applications see the recent article by WEARE (1987). For a discussion of the application of these models to site assessment see WEARE et al. (1986).

At present our models are limited to the components of the seawater system $\left(\mathrm{Na}^{+}, \mathrm{Mg}^{2+}, \mathrm{Ca}^{2+}, \mathrm{H}^{+}, \mathrm{Cl}^{-}, \mathrm{SO}_{4}^{2-}, \mathrm{HCO}_{3}^{-}, \mathrm{CO}_{3}^{2-}, \mathrm{CO}_{2}\right)$, together with the borate species 
and $\mathrm{SiO}_{2}$. While this model is of sufficient generality to be of use in many assessment problems and has been incorporated into the generally available computer codes developed by D.O.E. (EQ3/6 see WOLERY, 1979; 1983), the chemistry of a number of important natural water processes of interest in repository development fall outside the range of components included in the model and therefore cannot be treated.

An important such example is aluminium. Aluminum is one of the most abundant elements in the earth's crust. Yet its aqueous chemistry is poorly understood. Because of its small ionic size and high charge it tends to form strong complexes with some anions in solution. In particular, a variety of hydroxide and fluoride complexes have been identified and a number of attempts have been made to measure their stability. Aluminum is present in many minerals in repository formations and backfills. The solubilities of such minerals are deternined by the activity of aluminum species in solution. The activity of an ion in solution is a strong function of the hydrolysis and formation of other complexing species in solution which bind the ion and decrease its concentration in the free form. Therefore, an accurate knowledge of the hydrolysis and formation of other complexes of aluminum in solution is essential to the prediction of the chemical behavior of aluminum bearing minerals and thus the long term integrity of the repository.

In addition it is necessary to understand the chemistry of the interaction of the canister materials such as copper and iron with natural waters. The initial stages of the modeling program in these systems will concentrate on the identification and use of existing data to produce a preliminary model. This will allow us to concentrate our efforts on the experimental work needed to the provide additional thermodynamic data needed to assist in modeling these interactions.

\section{THE ALUMINUM SYSTEM}

In this phase of the program, the primary objective will be to continue the development of an accurate model of the aluminum-water system over the temperature range $25-95^{\circ} \mathrm{C}$, 
and for a range of background salt concentrations and compositions. This system is characterized by the formation of complex hydroxy-aluminum species. At low aluminum concentration the species in solution appear to be of the form $\mathrm{Al}\left(\mathrm{OH}_{h}\right)_{h}$. While there is general agreement as to the stoichiometry of these species at low concentrations of aluminum, there is considerable controversy as to their formation constants (see Table 1).

Table 1. Hydrolysis constants at $25^{\circ} \mathrm{C}$ for aluminum hydroxide species, and the solubility product of Gibbsite.

\begin{tabular}{lccc}
\hline & MAY et al. (1979) & $\begin{array}{c}\text { BAES and MESMER } \\
(1976)\end{array}$ & EQ3 \\
Species & & $\ln K_{\mathrm{H}}^{\dagger}$ & \\
\hline $\mathrm{Al}(\mathrm{OH})^{2+}$ & -11.49 & -11.44 & -10.91 \\
$\mathrm{Al}(\mathrm{OH})_{2}^{+}$ & -23.33 & -21.41 & - \\
$\mathrm{Al}(\mathrm{OH})_{3}(\mathrm{aq})$ & - & -34.54 & - \\
$\mathrm{Al}(\mathrm{OH})_{4}^{-}$ & -51.02 & -52.96 & -51.02 \\
$\mathrm{Al}_{2}(\mathrm{OH})_{2}^{4+}$ & - & -17.73 & - \\
$\mathrm{Al}_{13} \mathrm{O}_{4}(\mathrm{OH})_{24}^{7+}$ & - & -227.33 & - \\
& & $-\ln K_{\text {sol }}^{\ddagger}$ & 19.572 \\
$\left.\mathrm{Al}^{(\mathrm{OH}}\right)_{3}(\mathrm{~s})$ & 18.675 & & 18.328 \\
\hline
\end{tabular}

There appears to be fairly general agreement as to the first and fourth equilibrium constants (for the species $\mathrm{Al}(\mathrm{OH})^{2+}$ and $\mathrm{Al}(\mathrm{OH})_{4}$ ). However, formation constants for the intermediate species are very poorly known. These remarks apply to systems at zero concentration of background salt with low concentrations of aluminum. The information needed to model the system in a mixed brine at any concentration does not exist. Furthermore if the concentration of $\mathrm{Al}$ is high (greater than $10^{-4} \mathrm{~mol} \cdot \mathrm{kg}^{-1}$ ) new hydration species (e.g. $\mathrm{Al}_{13}(\mathrm{OH})_{32}$ ) become important. The structural and thermal properties of these polymeric species are complicated and controversial. Fortunately, for natural water systems near chemical equilibrium the aluminum concentration is kept very low (less than $10^{-5}$ 
mol. $\mathrm{kg}^{-1}$ ) by the preserse of very insoluble hydroxide and oxy-hydroxide phases. Therefore polymeric species such as $\mathrm{Al}_{13}(\mathrm{OH})_{32}$ may not be important to the assessment of repository performance.

The long range goal of our program is to develop a highly accurate model of these hydrolysis equilibria as a furiction of temperature, pressure and composition. This is an ambitious undertaking and will require the careful evaluation of a large data base much of which does not exist at present. The work proposed here provides the essential groundwork for this undertaking.

\section{Current Experimental Progress}

The primary emphasis during earlier periods of this contract has been placed on the acquisition of data to be used to build a high quality model of the aluminum system over the range of temperature from $25^{\circ} \mathrm{C}$ to $100^{\circ} \mathrm{C}$. The first priority in studying the aluminum system was to obtain information about the behavior of the $\mathrm{Al}^{3+}$ ion in aqueous solution. This was studied by using the following cell:

$$
\text { Pt }\left|\mathrm{H}_{2}(\mathrm{~g}, 1 \mathrm{~atm})\right| \mathrm{AlCl}_{3}\left(m_{1}\right), \mathrm{HCl}\left(m_{2}\right)|\mathrm{AgCl}(\mathrm{s})| \mathrm{Ag} \text {. }
$$

As the solutions in the cell are acidic, there is very little hydrolysis to form species such as $\mathrm{Al}(\mathrm{OH})^{2+}$. This cell has been used to measure the activity of $\mathrm{HCl}$ in $\mathrm{AlCl}_{3}$ solutions, at various ionic strength ratios, over a range of ionic strengths $\left(0.1-3.0 \mathrm{~mol} \cdot \mathrm{kg}^{-1}\right)$ and temperatures $\left(0-95^{\circ} \mathrm{C}\right)$. Unfortunately the data at $95^{\circ} \mathrm{C}$ are of significantly poorer quality than those at lower temperatures. (This is because of the open cells used. Better high temperature data could probably be obtained using closed cells.) These data on the $\mathrm{AlCl}_{3}$ system will be written up as a research paper which will be submitted to the Journal of Solution Chemistry.

A graduate student (Mr. Wei-Jun Cai) has developed methods which use a coulometric procedure to generate base in $\mathrm{NaCl}$ media. (This approach is discussed in greater detail below.) Now that we have shown that this can be done successfully using our apparatus, 
we have modified this method to enable us to investigate aluminum hydrolysis reactions at elevated temperatures (up to $90^{\circ} \mathrm{C}$ ). As our data in this system becomes available it will be input into our data fitting programs and the relevant parameters found.

\section{Experimental Research Plan}

We will employ the titration methods we have developed previously. These are similar to those used by BIEDERMANN (1956) and BIEDERMANN and FERRI (1982) in their elegant studies of the hydrolysis of $\mathrm{In}^{3+}$ in perchlorate media. The key to accurate measurements in the aluminum system depends on three principal areas: (1) minimizing the acidic/basic impurities in the various electrolyte solutions used as background ionic media, (2) the use of a high quality e.m.f. measuring system, and (3) the use of coulometric techniques to generate iydroxide ion quantitatively in ionic media. The coulometric generation of hydroxide ion allows the addition of hydroxide to be very slow and controlled, thus minimizing the possibility that high local concentrations of hydroxide ion will cause precipitation of $\mathrm{Al}(\mathrm{OH})_{3}$. We have successfully set up and tested a coulometric titration system based on a constant current source (see FACILITIES AVAILABLE) and used this to study the levels of impurity in our background media.

The high accuracy of coulometric generation of hydroxide ion $( \pm 0.02 \%)$, combined with high precision e.m.f. measurements $( \pm 0.03 \mathrm{mV})$ should make it possible to estimate the association constants for aluminum hydrolysis species in media of varying composition and ionic strength. This will be achieved by the least-squares processing of titration data obtained using an automated potentiometric titration apparatus (see for example BRAUNER and SILLÉN, 1968; ARENA et al., 1979; LEGGETT, 1985). We intend to perform such titrations in a variety of ionic solutions containing varying concentrations of $\mathrm{Al}^{3+}$ ion over a range of temperatures $\left(40-90^{\circ} \mathrm{C}\right)$ and ionic strengths. The ensemble of data obtained can then be treated using our software to obtain Pitzer parameters, and standard chemical potentials simultaneously. At higher temperatures, it is desirable to work with sealed 
systems. Again, the coulometric generation of hydroxide ion will be more convenient than the design of a high pressure titration system. We hope to design a coulometric system which can be used under pressure. Ideally, this will be a system in which the two electrode processes do not need to be physically separated by a liquid junction. Such a system is provided by the cell reaction

$$
\mathrm{PbO}_{2}(\mathrm{~s})+4 \mathrm{H}^{+}+2 \mathrm{Ag}(\mathrm{s})=\mathrm{Pb}^{2+}+2 \mathrm{Ag}^{+}+2 \mathrm{H}_{2} \mathrm{O},
$$

which was used by BIEDERMANN and FERRI (1982) in perchlorate media. We therefore propose to test this reaction over a wide range of temperature to assess its usefulness for this purpose. If we find that it is, we shall incorporate the coulometric electrodes into our cell for higher temperatures, and show that this is a practical approach for studying hydrolysis reactions at high temperatures. Again we would like to emphasize that our final goal is a model over a wide temperature range $\left(0-150^{\circ} \mathrm{C}\right)$.

\section{Current Modeling Progress}

We have begun the development of our general model for aiuminum by developing a model of the behavior of $\mathrm{Al}^{3+}$ at low $\mathrm{pH}$. At $\mathrm{pH}$ values less than 3 the various hydrolysis species would be expected to be at essentially zero concentration because hydroxide ion concentration is very low. This leaves the unassociated $\mathrm{Al}^{3+}$ and $\mathrm{H}^{+}$as the principal species in solution. As has been discussed previously (see e.g. WEARE, 1987), our models are based on the parameterization of the Pitzer phenomenological equations which give the activity coefficients of solution species as a function of composition. In the initial period of this research the cell measurements discussed in the first part of this proposal have provided the necessary data to evaluate the parameters for the interactions between $\mathrm{Al}^{3+}, \mathrm{H}^{+}$ and $\mathrm{Cl}^{-}$species.Basically these expcriments measure the activity of $\mathrm{HCl}$ as a function of solution composition. In earlier work we have developed an accurate model of $\mathrm{H}^{+}-\mathrm{Cl}^{-}$ interactions. The small changes in the e.m.f. of the cell due to the addition of the $\mathrm{Al}^{3+}$ species provide information as to the interaction of the $\mathrm{Al}^{3+}$ with $\mathrm{Cl}^{-}$ions and interactions 
between $\mathrm{Al}^{3+}$ and $\mathrm{H}^{+}$. Under other funding we have developed an extensive library of data reduction software. This software is especially designed to simultaneously treat a variety of measurements including e.m.f. measurements. During the present period of support we will have made progress toward the parameterization of the data on the $\mathrm{Al}^{3+}$ and $\mathrm{H}^{+}$system discussed above this will provide a basis for describing the aluminum system in acid solutions and to begin the description of the formation of hydrolysis species.

\section{Modeling Research Plan}

In this period of support we will continue the parameterization of the acid side chemistry of aluminum to provide a model over the temperature range 25 to $95^{\circ} \mathrm{C}$. The parameterization of the hydrolysis behavior will be begun. The initial temperature chosen will depend somewhat on the experimental conditions chosen to avoid precipitation and equilibration problems.

The experimental part of our program should start to provide new titration data in the near future. This data along with the existing solubility data of May and new highly accurate solubility data taken by the Oak Ridge group (Don Palmer and Dave Wesolowski, personal communication) will be incorporated in the data base. The data of May has recently been questioned by APYS et al. (1986) However, the problems that they identified will not affect the use of the data to evaluate equilibrium constants. Our expectation is that a model consistent with both solubility and e.m.f. data can be produced. The reliability of such a model to describe chemistry in mixed systems would be expected to be considerably higher than a model based on solubility alone. At present such a model does not exist.

\section{THE AQUEOUS CHEMISTRY OF CANISTER MATERIALS}

The integri:y of a waste repository will be affected by the interactions of materials comprising the waste canister with the solutions that may be infiltrating the containment area. The Yucca Mountain Project is evaluating six candidate materials for waste package 
UCSD 901101

container. These six materials fall into two alloy families: (1) austenic materials (AISI 304L, AISI 316 and Alloy 825) and (2) copper-based materials (CDA 102, CDA 613 and CDA 715). The principal metals involved are thus iron (in the austenic materials) and copper. The particular alloys chosen have excellent corrosion resistance but nevertheless the exact modes of corrosion are not well understood. The aqueous solutions that enter this region would be expected to have approximately the composition of the formation fluids known to the area. However, on interaction with the canister, new species including the elements iron and copper will be introduced into the formation water. While species such as these are not uncommon in natural water systems, there presence is generally of less importance than that for example aluminum. For this reason the natural water chemistry of these systems is even less well understood than that of the aluminum system. Nevertheless, just as in the aluminum system where the activity of $\mathrm{Al}^{3+}$ ions controls the solubility of aluminum containing minerals, the activity of iron and copper species will control the reactions of the canister with the formation fluid and the formation of iron and copper containing minerals and scales that may result from reactions of the canister with the infiltrating fluids. In order to predict this behavior and consequently the containment properties of the repository on the time scale necessary for licensing, it is necessary to develop a modei of the solution chemistry of these species.

As in the aluminum system this will require both modeling and an experimental program. Because of the expected chemical complexity of the iron and copper systems, a program which combines measurement with modeling will be considerable more efficient than separate programs. We believe that there is an additional benefit to the waste program in pursuing this research. The chemistry of these transition metal ions has certain similarities with some of the radioactive elements that may be encountered in a nuclear waste repository. We expect that our combined modeling and experimental research may provide insights to the development of highly accurate models for such radioactive species. 
Ground water in the Nevada site is expected to be relatively dilute. Therefore the objective will be to obtain a consistent set of standard chemical potentials for the iron and copper species in solution, particularly in their complexes with $\mathrm{OH}^{-}, \mathrm{HCO}_{3}^{-}$and $\mathrm{CO}_{3}^{2-}$ ions. At low concentrations other complexing species such as the chloride species are not expected to play an important role in the water chemistry.

\section{The Iron System}

Iron is stable in the +2 and +3 oxidation state over a wide range of $\mathrm{pH}$ and redox potential. Ferric ion $\left(\mathrm{Fe}^{3+}\right)$ is easily reduced to ferrous ion $\left(\mathrm{Fe}^{2+}\right)$, while ferrous ion is slowly oxidized by air. Both ferric and ferrous iron hydrolyze readily, however because of its higher charge, ferric ion forms stronger hydroxide species. The hydrolysis of ferric ion thus begins at a $\mathrm{pH}$ of one while that of ferrous ion begins at $\mathrm{pH} 7$.

Both ionic forms complex with a variety of ligands. As usual the strongest complexes are with hard class (a) ions such as fluoride and hydroxide. The strength of these complexing reactions is considerable larger for the +3 species. However, even in these systems the complexing is somewhat smaller than that of $\mathrm{Al}^{3+}$. The complexing with $\mathrm{Cl}^{-}$is quite weak especially for ferrous ions and is not expected to be important to the solution behavior at low chloride concentrations. Both species form fairly strong complexes with carbonate. This may be the only species other than the hydrolysis species that is of concern to this program. In Table 2 we summarize the speciation constants for some of the important species.

Table 2. Some association constants for iron and copper species (TURNER et al., 1981)

\begin{tabular}{lc}
\hline Species & $\log \mathrm{K}$ \\
\hline $\mathrm{Fe}(\mathrm{OH})^{+}$ & -9.5 \\
$\mathrm{Fe}(\mathrm{OH})_{2}^{+}$ & -20.60 \\
$\mathrm{Fe}(\mathrm{OH})^{2+}$ & -5.67
\end{tabular}




\begin{tabular}{lc}
$\mathrm{Fe}\left(\mathrm{CO}_{3}\right)^{2+}$ & 9.72 \\
$\mathrm{Cu}(\mathrm{OH})^{+}$ & -8.00 \\
$\mathrm{Cu}\left(\mathrm{OH}_{2}\right)_{2}$ & -17.3 \\
$\mathrm{CuCO}_{3}$ & 6.75 \\
\hline
\end{tabular}

\section{The Copper System}

Copper has one $4 \mathrm{~s}$ electron. Therefore it might be expected to adopt the +1 oxidation state. As is common in the transition metals however, the $9 \mathrm{~d}$ configuration is more stable. $\mathrm{Cu}^{+}$ions uisproportionate to neutral $\mathrm{Cu}$ and $\mathrm{Cu}^{2+}$ in normal oxygenated aqueous solution. $\mathrm{Cu}^{+}$concentrations are therefore expected to be very low. Because of the low charge $\mathrm{Cu}^{+}$, is not expected to hydrolyze extensively. We would expect most of the non-ideal behavior of this ion (in so far as the ion is present) to be describable in terms of non-ideal corrections in the basic 'Pitzer' equation.

$\mathrm{Cu}^{2+}$ interacts more strongly with ligands in solution (illustrated by the association constants included in Table 2). However, $\mathrm{Cu}^{2+}$ hydrolyzes only slightly before precipitation of insoluble hydroxides occurs. At present there is not even agreement as to the correct description of the speciation of these two elements in aqueous solutions. For example, in BAES and MESMER (1976), the $\mathrm{Cl}_{2}(\mathrm{OH})_{2}^{2+}$ is proposed as the major species in solution whereas TURNER et al. (1981) do not even give an association constant for this species, choosing instead $\mathrm{Cu}(\mathrm{OH})^{+}$. Mesmer states that the association constant for this species is uncertain.

\section{Experimental and Modeling Work}

The validity of a particular speciation model will depend somewhat on the composition of the solution. For example dimeric species of copper would be expected to be more stable at high concentrations. Because of this, the initial stages of our program will concentrate on building a preliminary model of the iron and copper systems. This model will be used to 
investigate the behavior of the systems for the low concentration ranges appropriate to the Y.M.P. site. By comparing this model to existing experimental data we will be able to optimize the proposed experimental plan as well as learn about the potential experimental problems in the system.

Upon completion of this initial phase we shall embark on our series of experiments. The copper and iron systems have an advantage over the aluminum system in that it is possible to probe such systems spectroscopically. We expect such spectroscopic measurements to provide reasonably accurate determinations of speciation for considerably less effort than the thermodynamic measurements described for aluminum. Of course, as we have ongoing e.m.f. measurements we shall also use that approach to make measurements on the iron and copper systems. The general technique of spectroscopic measurements we shall use is described by BYRNE et al. (1981).

As this new data becomes available, it will be incorporated in a data base containing all the available measurements. This comprehensive data base will be used to obtain parameters for use in planning further experiments. 
UCSD 901101

\section{BIBLIOGRAPHY}

APPS J.A., NEIL J. M. and JUN C.-H. (1986) Thermochemical properties of gibbsite, boehmite, diaspore and the aluminate ion between 0 and $350^{\circ} \mathrm{C}$. Lawrence Berkely Laboratory, LBL-21482.

ARENA G., Rizzarelli E., and SAMARTANo S. (1979) A non-linear least squares approach to the refinement of all parameters involved in acid-base titrations. Talanta 26, 1-14.

BAES C. F. and MESMER R. E. (1976) The hydrolysis of cations, Wiley-Interscience.

BIEDERMANN G. (1956) Studies on the hydrolysis of metal ions. Part 14. The hydrolysis of the indium (III) ion, In $^{3+}$. Arkiv Kemi 9, 277-293.

BIEDERMANN G. and FERRI D. (1982) On the polynuclear hydrolysis of the indium ion; $\mathrm{In}^{3+}$. Acta Chem. Scand. A36, 611-622.

Brantley S. L., Crerar D. A., Møller N. E., and Weare J. H. (1984) Geochemistry of a modern marine evaporite: Bocana de Virrilá, Peru. J. Sed. Petrol. 54, 477-462.

BRAUNIR P. and SILEÉN L. G. (1968) High-speed computers as a supplement to graphical methods. 9. Adjustment for systematic experimental errors and other "group parameters" in LETAGROP. Applications to potentiometric titrations. Ark. Kemi 31, 365-376.

BYRNE R. H., YOUNG R. W. and MILLER W. L. (1981) Lead chloride complexation using ultraviolet molar absorptivity characteristics. J. Solution Chem. 10, 243-251.

EUGSTER H. P., HARVIE C. E. and WEARE J. H. (1980) Mineral equilibria in a six component seawater system, $\mathrm{Na}-\mathrm{K}-\mathrm{Mg}-\mathrm{Ca}-\mathrm{Cl}-\mathrm{SO}_{4}-\mathrm{H}_{2} \mathrm{O}$ at $25^{\circ} \mathrm{C}$. Geochim. Cosmochim. Acta 44, 1335-1347.

FELMY A. R. and WEARE J. H. (1986) The prediction of borate mineral equilibria in natural waters: application to the Searles Lake. Geochim. Cosmochim. Acta 50,27712783.

HARVIE C. H. and WEARE J. H. (1980) The prediction of mineral solubilities in natural waters: the $\mathrm{Na}-\mathrm{K}-\mathrm{Mg}-\mathrm{Ca}-\mathrm{Cl}-\mathrm{SO}_{4}-\mathrm{H}_{2} \mathrm{O}$ system from zero to high concentration at $25^{\circ} \mathrm{C}$. Geochim. Cosmochim. Acta 44, 981-997.

HARVIE C. H., MøLleR N. and Weare J. H. (1980) The prediction of mineral solubilities in natural waters: the $\mathrm{Na}-\mathrm{K}-\mathrm{Mg}-\mathrm{Ca}-\mathrm{Cl}-\mathrm{SO}_{4}-\mathrm{OH}-\mathrm{HCO}_{3}-\mathrm{CO}_{3}-\mathrm{H}_{2} \mathrm{O}$ system to high ionic strengths at $25^{\circ} \mathrm{C}$. Geochim. Cosmochim. Acta 48,723-751. 
HARVIE C. H., WEARE J. H., HARVIE L. A., and EUGSTER H. P. (1980) Evaporation of seawater: calculated mineral sequences. Science 208, 498-500.

HARVIE C. H., MølleR N. E. and WEARE J. H.(1984) The prediction of mineral solubilities in natural waters: the $\mathrm{Na}-\mathrm{K}-\mathrm{Mg}-\mathrm{Ca}-\mathrm{H}-\mathrm{Cl}-\mathrm{SO}_{4}-\mathrm{OH}-\mathrm{HCO}_{3}-\mathrm{CO}_{3}-\mathrm{H}_{2} \mathrm{O}$ system to high ionic strengths at $25^{\circ} \mathrm{C}$. Geochim. Cosmochim. Acta 48, 723-751.

LEGGETT D. (1985) Compitational methods for the calculation of stability constants. Plenum.Press.

MAY H. M., HELMKE P. A., and JACKSON M. L. (1979) Gibbsite solubility and thermodynamic properties of hydroxy-aluminum ions in aqueous solution at $25^{\circ}$. Geochim. Cosmochim. Acta 43, 861-868.

MESMER R. E. and BAES C. F. (1971) Acidity measurements at elevated temperatures. V. Aluminum ion hydrolysis. Inorg. Chem. 10, 2290-2296.

MøLLER N. (1988) The prediction of mineral solubilities in natural waters. A chemical equilibrium model for the $\mathrm{Na}-\mathrm{Ca}-\mathrm{Cl}-\mathrm{SO}_{4}-\mathrm{H}_{2} \mathrm{O}$ system at high $\mathrm{T}$ and concentration. Geochim. Cosmochim. Acta 52, 821-837.

MØLLER N., GREENBERG, J. P. and WEARE J. H. The prediction of mineral solubilities in natural waters: the $\mathrm{Na}-\mathrm{K}-\mathrm{Mg}-\mathrm{Ca}-\mathrm{Cl}-\mathrm{SO}_{4}-\mathrm{H}_{2} \mathrm{O}$ system from zero to high concentration and from 25 to $250^{\circ} \mathrm{C}$ (in preparation).

MøLLER N., GREENBERG, J. P. and WEARE J. H. $\mathrm{CO}_{2}$ disequilibrium in the evaporation of seawater. (in preparation).

PITZER K. S. (1972) Thermodynamics of electrolytes. 1. Theoretical basis and general equations. J. Phys. Chem. 77, 268-277.

PITZER K. S. (1987) A thermodynamic model for aqueous solutions of liquid-like density. In Thermodynamic modeling of geological materials: minerals, fluids and melts. (eds. I. S. E. Carmichael and H. P. Eugster), American Mineralogical Society, Reviews in Mineralogy 17, 97-142.

SPENCER R. J., EUGSTER H., and JONES B. F. (1985) Geochemistry of Great Salt Lake, Utah. II. Pleistocene-Holocene evolution. Geochim. Cosmochim. Acta 49, 739-747.

STUMM W. and MORGAN J. J. (1981) Aquatic chemistry, Wiley-Interscience.

TURNER D. R., WHITFIELD, M. and DICKSON A. G. (1981) The equilibrium speciation of dissolved components in freshwater and seawater at $25^{\circ} \mathrm{C}$ and 1 atm pressure. Geochim. Cosmochim. Acta 45, 855-881. 
WEARE J. H. (1987) Models of mineral solubility in concentrated brines with application to field observations. In Thermodynamic modeling of geological materials, minerals, fluids and melts. (eds. I. S. E. Carmichael and H. P. Eugster), American Mineralogical Society, Reviews in Mineralogy 17, 143-176.

Weare J. H., Møller, N. Greenberg J. P. and FelMy A. R. (1986) Chemical equilibrium in mineral formation and digenesis in the carbonate evaporite system: an assessment of chemical model application to site performance. Proceedings of the Workshop on Geochemical Modeling, Fallen Leaf, California.

WOLERY T. J. (1979) Calculation of chemical equilibrium between aqueous solution and minerals: the EQ3/6 software packageLawrence Livermore Laboratory report, UCRL52658.

WOLERY T. J. (1983) EQ3NR A computer program for geochemical aqueous speciationsolubility calculations: user's guide and documentation.Lawrence Livermore Laboratory report, UCRL-53414. 

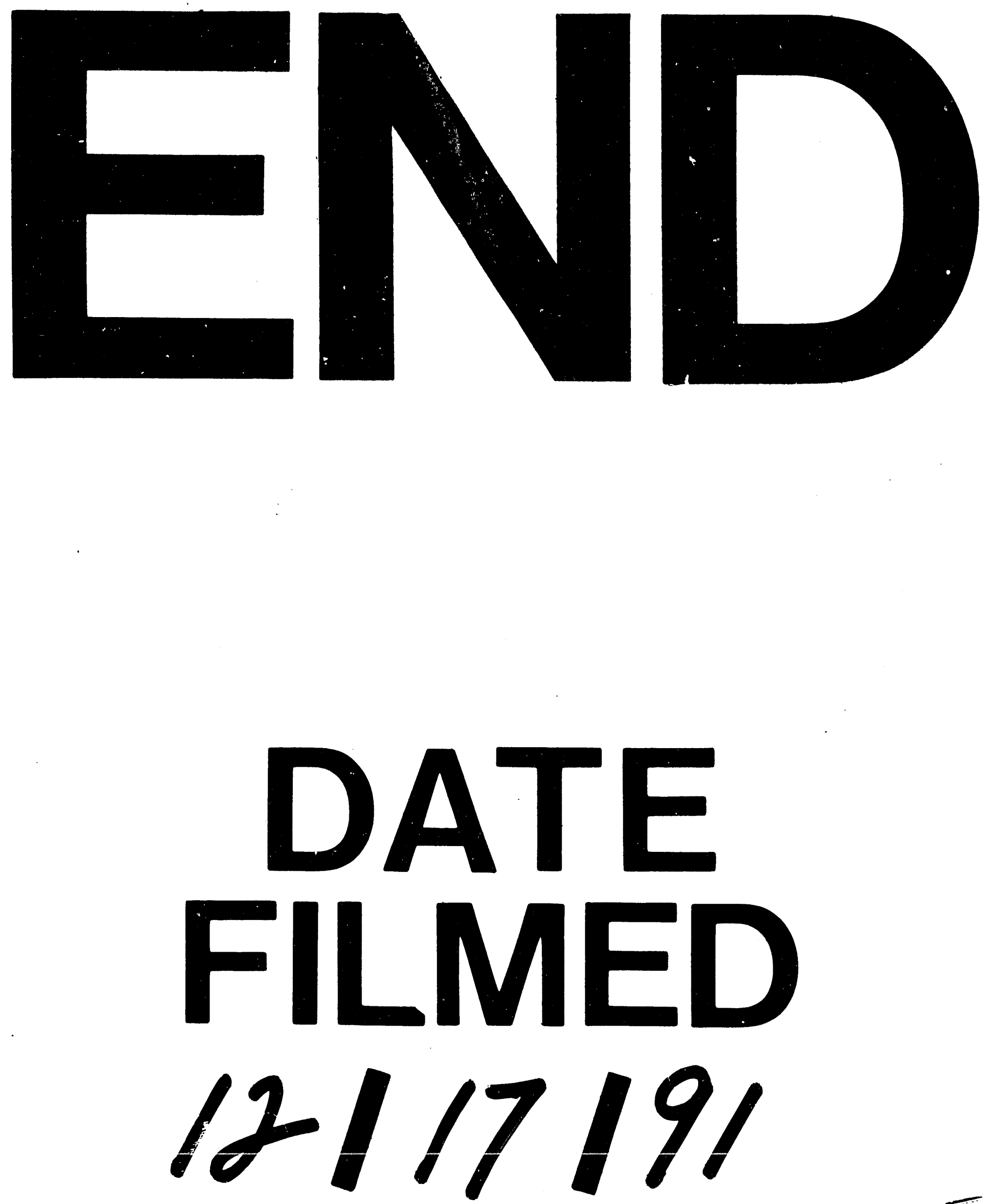
